\title{
Reaksi Pasar atas Pengumuman Penurunan Bank Indonesia 7-Day Reverse Repo Rate
}

\section{Anak Agung Gede Rama Sayudha ${ }^{1}$ Fakultas Ekonomi dan Bisnis Universitas Udayana, Indonesia}

\author{
Ni Ketut Rasmini ${ }^{2}$ \\ Fakultas Ekonomi dan Bisnis \\ Universitas Udayana, Indonesia
}

Surel : raamsayudhaa@gmail.com

\section{ABSTRAK}

Tujuan penelitian untuk membuktikan reaksi pasar atas pengumuman penurunan Bank Indonesia 7-Day Reverse Repo Rate pada sektor properti dan perbankan. Penelitian ini berupa studi peristiwa dengan periode penelitian selama 7 hari. Proses penentuan sampel menggunakan teknik purposive sampling. Diperoleh sebanyak 32 perusahaan perbankan dan perusahaan properti sebagai sampel. Reaksi pasardiukur menggunakan abnormal return. Paired samples $t$-test dan wilcoxon signed rank test digunakan sebagai teknik analisis data. Hasil penelitian pada kedua sektor membuktikan bahwa tidak adanya perbedaan antara abnormal return sebelum dan setelah pengumuman penurunan BI 7-Day Reverse Repo Rate. Berdasarkan hasil penelitian, pengumuman ini tidak menimbulkan reaksi pada pasar. Hal ini dapat disebabkan oleh investor yang menganggap bahwa pengumuman ini tidak dapat mempengaruhi kinerja perusahaan dalam jangka pendek serta mempertimbangkan sentimen-sentimen lainnya.

Kata Kunci: BI 7-Day Reverse Repo Rate; Studi Peristiwa; Abnormal Return; Reaksi Pasar.

\section{Market Reaction Over The Announcement of Bank Indonesia 7-Day Reverse Repo Rate Decreasement}

\begin{abstract}
The purpose of this study is to investigate the reaction of the Indonesian capital market to the announcement of a reduction in the Bank Indonesia 7-Day Reverse Repo Rate on the property and banking sectors. This study employs an event study with a seven-day observation period. The sampling technique used was the purposive sampling technique. The sample size for the banking sector was 32 companies, and the sample size for the property sector was 30 companies. Anomaly returns were used to gauge market reaction. The researchers used the paired samples t-test and the Wilcoxon signed rank test to analyze the data. The results for both sectors revealed that no market reaction was detected as a result of the announcement. This may be caused by investors thought that the announcement can't affect the company's performance in short term and also considering the other sentiments.
\end{abstract}

Keywords: $\quad$ BI 7-Day Reverse Repo Rate; Event Study; Abnormal Return; Market Reaction.

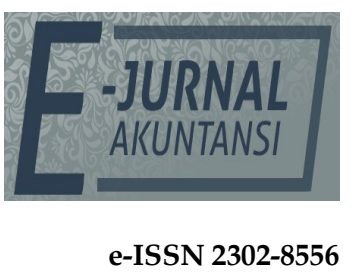

Vol. 31 No. 8

Denpasar, Agustus 2021 Hal. 1907-1917

DOI:

10.24843/EJA.2021.v31.i08.p03

PENGUTIPAN:

Sayudha, A.A.G.R.S., \& Rasmini, N.K. (2021). Reaksi

Pasar atas Pengumuman Penurunan Bank Indonesia 7-

Day Reverse Repo Rate. EJurnal Akuntansi, 31(8), 1907-

1917

RIWAYAT ARTIKEL: Artikel Masuk:

25 November 2020

Artikel Diterima: 5 Juli 2021

Artikel dapat diakses : https://ojs.unud.ac.id/index.php/Akuntansi/index 


\section{PENDAHULUAN}

Transaksi saham pada pasar modal sangat dipengaruhi oleh suatu informasi yang diterima investor. Adanya informasi mengakibatkan investor dapat berpikir secara rasional terhadap pengambilan keputusan guna meminimalisir risiko. Suatu informasi yang diperoleh investor akan bernilai apabila dapat mengubah pengambilan keputusan investor. Keputusan investor ditunjukkan dengan tindakan transaksi jual beli saham yang tercermin oleh perubahan harga saham yang berdampak pada return yang diterima. Keputusan investasi yang dilakukan investor merupakan reaksi yang mereka terima atas terjadinya suatu peristiwa (Wibowo, 2017). Suatu peristiwa dikatakan memiliki kandungan informasi apabila terjadi reaksi pasar di sekitar tanggal peristiwa. Reaksi pasar ditunjukkan dengan adanya perubahan harga saham perusahaan yang dapat diukur dengan abnormal return (Hartono, 2017:644). Jika prospek perusahaan emiten dipandang baik atau memiliki potensi akibat terjadinya suatu peristiwa, maka permintaan saham oleh investor akan cenderung meningkat. Tingginya permintaan saham akan berdampak pada peningkatan harga saham. Sebaliknya, jika terjadi suatu peristiwa yang dipandang dapat merugikan perusahaan emiten, maka permintaan saham cenderung akan menurun yang berakibat pada penurunan harga saham (Pratiwi, 2018).

Suku bunga merupakan salah satu faktor yang sangat berpengaruh pada kesehatan perekonomian suatu negara (Pratama \& Tjun, 2018). Tingkat suku bunga mempunyai pengaruh yang sangat luas, sehingga dapat mempengaruhi dunia usaha dalam pengambilan keputusan. Suku bunga BI Rate atau sejak 19 Agustus 2016 bernama BI 7-Day Reverse Repo Rate merupakan faktor yang sering dipertimbangkan oleh investor dalam berinvestasi. Fluktuasi suku bunga acuan dapat diperhitungkan sebagai faktor yang dapat mempengaruhi pasar. Tingkat suku bunga dinilai memiliki dampak langsung terhadap perekonomian. Berdasarkan kajian empiris, suku bunga acuan mempengaruhi harga saham emiten secara terbalik. Kenaikan suku bunga acuan merupakan suatu bad news yang menyebabkan harga saham turun. Sebaliknya, penurunan tingkat suku bunga merupakan good news yang menyebabkan permintaan saham meningkat. Hal ini sejalan dengan hasil penelitian Wuhan et al. (2015), yaitu tingkat suku bunga berbanding terbalik terhadap harga saham. Karim (2015), menyebutkan bahwa suku bunga yang rendah akan mendorong aktivitas investasi yang menyebabkan meningkatnya permintaan harga saham. Penurunan suku bunga acuan memungkinkan investor lebih tertarik untuk berinvestasi pada aset yang lebih berisiko seperti saham. Semakin kecil return dari deposito atau obligasi maka semakin besar kemungkinan investor untuk beralih investasi di saham. Adapun beberapa penelitian yang mendukung hasil penelitian tersebut, antara lain: Ramsharan (2019), Hajilee \& Nassel (2017), Okechukwu et al. (2019), Amarasinghe (2015), Rjoub, (2017), Dadrasmoghadam \& Akbari (2015), Okoro et al. (2018), dan Oshaibat \& Majali (2016).

Bank Indonesia 7-Day Reverse Repo Rate merupakan suku bunga kebijakan baru yang berlaku efektif sejak 19 Agustus 2016, menggantikan BI Rate. Instrumen BI 7-Day (Reverse) Repo Rate digunakan sebagai suku bunga kebijakan baru karena dapat secara cepat memengaruhi pasar uang, perbankan dan sektor riil. Pada tahun 2019, Bank Indonesia mengumumkan penurunan BI 7-Day Reverse Repo Rate 
selama empat bulan berturut-turut pada bulan Juli hingga Oktober. Rapat Dewan Gubernur (RDG) Bank Indonesia pada bulan Juli tahun 2019, memutuskan untuk menurunkan suku bunga acuan BI 7-Day Reverse Repo Rate (BI-7DRR) sebesar 25 basis poin (bps) dari 6\% menjadi 5,75\%. Kebijakan tersebut dilatarbelakangi oleh rendahnya prakiraan inflasi dan untuk mendorong momentum pertumbuhan ekonomi di tengah kondisi ketidakpastian pasar keuangan global yang menurun. Pada bulan berikutnya, Bank Indonesia kembali menurunkan suku bunga acuan secara konsisten sebesar 25 basis poin selama tiga bulan berikutnya hingga level $5 \%$ pada tanggal 24 Oktober 2019.

Keputusan ini dinilai dapat mendorong momentum pertumbuhan ekonomi domestik di tengah kondisi ekonomi global yang melambat (Indriyani, 2016). Keputusan Bank Indonesia menurunkan suku bunga acuan merupakan sentimen positif bagi Indeks Harga Saham Gabungan (IHSG). Penutupan IHSG pada hari Kamis tanggal 24 Oktober 2019 yang mengalami kenaikan sebesar 10,93 poin atau 0,17 persen ke posisi 6.191,65. Hal ini mengindikasikan bahwa pasar menanggapi secara positif pengumuman penurunan BI-7DRR pada tanggal 24 Oktober 2019 yang merupakan penurunan keempat sejak bulan Juni.

Terdapat beberapa penelitian mengenai reaksi pasar atas pemberlakuan kebijakan dari pemerintah. Dalam penelitian Mahendra (2019), diperoleh hasil bahwa pasar bereaksi atas kenaikan BI 7-Day Reverse Repo Rate. Hasil yang berbeda diperoleh dalam penelitian Anjani \& Wahyuni (2019), yang menunjukkan bahwa tidak terdapat perbedaan average abnormal return sebelum dan sesudah peristiwa kenaikan suku bunga BI 7-Day Reverse Repo Rate pada tanggal 29 Juni 2018 yang berarti bahwa pasar tidak bereaksi akan peristiwa tersebut. Inkonsistensi hasil penelitian tersebut dapat disebabkan oleh adanya perbedaan karakteristik industri yang diteliti serta data atau pendekatan yang digunakan. Maka dari itu, pengujian kandungan informasi atas pengumuman penurunan BI 7-Day Reverse Repo Rate perlu dilakukan dengan menggunakan sampel yang lebih spesifik yaitu per sektor.

Adapun berbagai penelitian reaksi pasar terdahulu yang memiliki kaitan dengan pemberlakuan kebijakan dari pemerintah antara lain: Dewi (2017), menguji reaksi pasar atas diumumkannya suatu kebijakan tentang Daftar Negatif Investasi (DNI). Hasil penelitiannya menunjukkan bahwa pasar bereaksi atas diumumkannya pengumuman tersebut dan reaksi tertinggi ditunjukkan oleh sektor usaha yang diuntungkan. Mahendra (2019) menguji reaksi pasar atas kenaikan BI 7-DRRR pada perusahaan LQ-45, memperoleh hasil bahwa pasar bereaksi di sekitar tanggal pengumuman. Anjani \& Wahyuni (2019) menguji reaksi investor atas kenaikan suku bunga acuan yang memperoleh hasil bahwa pengumuman kenaikan suku bunga BI 7-DRRR tidak menimbulkan reaksi pada pasar.

Dalam teori efisiensi pasar dijelaskan bahwa pasar modal dapat disebut efisien apabila mampu merespon informasi yang tersedia serta bagaimana informasi tersebut selanjutnya mampu mempengaruhi keputusan investor sehingga terjadi perubahan harga (Fama, 1970). Pasar dikatakan efisien jika harga pada pasar mencerminkan seluruh informasi yang tersedia. Teori ini menyebutkan bahwa pasar dikatakan efisien apabila. Hartono (2017) menjelaskan bahwa investor membutuhkan informasi dalam pengambilan keputusan yang 
dapat didasari oleh adanya suatu pengumuman atau peristiwa yang mampu mempengaruhi perubahan harga saham. Adapun perubahan atau reaksi tersebut berupa reaksi positif apabila informasi bersifat good news dan reaksi negatif apabila informasi bersifat bad news.

Konsep efisiensi pasar membahas bagaimana pasar merespon informasiinformasi yang masuk dan bagaimana informasi tersebut selanjutnya bisa mempengaruhi pergerakan harga sekuritas menuju harga keseimbangan yang baru, Pasar bereaksi karena adanya peristiwa yang mengandung suatu informasi yang dapat mengubah nilai perusahaan sehingga akan mengubah perilaku investor dalam berinvestasi. Reaksi pasar dilihat dari adanya perbedaan abnormal return disekitar tanggal peristiwa. Abnormal return diuji untuk mengetahui adanya reaksi pasar terhadap suatu peristiwa (event). Perusahaan yang mendapat keuntungan dari suatu informasi dapat menghasilkan abnormal return yang positif, sedangkan perusahaan yang dirugikan oleh peraturan akan menghasilkan abnormal return negatif (Huy et al, 2017).

Ginting (2016) dalam penelitiannya membuktikan bahwa tingkat suku bunga berpengaruh negatif terhadap harga saham. Hasil pengujian hipotesis bertanda negatif menunjukkan pengaruh yang berlawanan antara tingkat suku bunga terhadap harga saham, yang berarti semakin tinggi tingkat suku bunga maka harga saham cenderung akan semakin rendah. Hasil penelitian ini sejalan dengan penelitian Munawaroh \& Handayani (2019), yang membuktikan bahwa suku bunga mempengaruhi harga saham secara terbalik atau dalam keadaan ceteris paribus yang berarti jika suku bunga meningkat, maka harga saham akan mengalami penurunan. Mujiburrahman (2016) dalam penelitiannya juga membuktikan bahwa korelasi tingkat suku bunga terhadap harga saham adalah kuat dan arahnya negatif, dimana hubungan negatif tersebut menunjukkan jika tingkat suku bunga meningkat maka harga saham akan mengalami penurunan.

Pengujian hipotesis ini merupakan pengujian statistik terhadap abnormal return yang bertujuan untuk mengetahui apakah pasar sektor perbankan bereaksi disekitar tanggal pengumuman penurunan BI 7-Day Reverse Repo Rate tahun 2019. Reaksi pasar ditunjukkan dengan adanya abnormal return disekitar tanggal pengumuman. Jika abnormal return yang signifikan adalah lebih besar dari nol atau bernilai positif maka pengumuman ini merupakan good news. Jika abnormal return yang signifikan bernilai negatif, maka pengumuman ini merupakan bad news.

Fitriyana (2017) dalam penelitiannya membuktikan bahwa terdapat pengaruh negatif dan signifikan antara tingkat suku bunga terhadap profitabilitas (ROA) Bank Umum di Indonesia periode 2012-2015. Kebijakan tingkat suku bunga yang ditetapkan oleh Bank Indonesia secara langsung mempengaruhi kegiatan operasional dalam hal pembiayaan dan penyaluran dana pada perbankan di Indonesia. Semakin tinggi tingkat suku bunga maka semakin kecil ROA pada bank, begitu pula sebaliknya menurunnya tingkat suku bunga maka akan meningkatkan perolehan pendapatan pada perbankan. Penelitian Kurniasari et al (2018) juga membuktikan bahwa suku bunga berpengaruh negatif terhadap return saham perbankan, yang artinya bahwa tingkat suku bunga maka harga saham cenderung akan menurun. 
$\mathrm{H}_{1}$ : Terdapat perbedaan average abnormal return sebelum dan setelah pengumuman penurunan BI 7-Day Reverse Repo Rate pada sektor perbankan.

Dalam penelitian Wibisono \& Octaviani (2019), indeks harga saham properti dipengaruhi oleh perubahan tingkat suku bunga secara signifikan namun dalam janga pendek. Indeks Harga Saham Properti selama ini dianggap sebagai indikator yang sangat penting di Bursa Efek Indonesia karena dapat digunakan untuk menganalisis kesehatan perekonomian Indonesia. Industri properti dan real estate seringkali merupakan sektor pertama yang memberikan sinyal kondisi perekonomian sebuah negara. Indeks Harga Saham Properti memiliki hubungan korelasi paling kuat dengan Indeks Harga Saham Keuangan. Hal ini dapat terjadi karena pembiayaan sektor properti terkait erat dengan perbankan. Masyarakat yang hendak membeli sebuah properti akan berhubungan dengan pihak perbankan, sehingga para pengembang dari sektor properti menggantungkan penjualannya pada pergerakan suku bunga dan pertumbuhan kredit (Wibisono \& Octaviani, 2019).

Sari (2019) dalam penelitiannya membuktikan bahwa kenaikan indeks saham sektor properti ditentukan oleh suku bunga. Hasil penelitiannya menyatakan bahwa suku bunga berpengaruh negatif signifikan dengan IHSG sektor properti. Artinya jika suku bunga rendah IHSG sektor properti cenderung akan meningkat. Peningkatan indeks saham sektor properti dikarenakan investor lebih banyak membeli saham dengan melihat faktor suku bunga. Maliskha et al (2017) dalam penelitiannya menyatakan bahwa suku bunga memberikan pengaruh terhadap IHSG karena suku bunga menjadi salah satu variabel yang diperhatikan oleh investor dalam berinvestasi. Meningkatnya BI Rate menyebabkan kenaikan pada suku bunga bank, hal ini dapat menurunkan minat investasi dalam bentuk saham properti dan real estate yang berimbas pada penurunan harga saham.

$\mathrm{H}_{2}$ : Terdapat perbedaan average abnormal return sebelum dan setelah pengumuman penurunan BI 7-Day Reverse Repo Rate pada sektor properti.

\section{METODE PENELITIAN}

Dalam menjawab permasalahan yang telah dirumuskan pada penelitian ini, akan dilakukan tahapan-tahapan. Mengidentifikasi tanggal pengumuman penurunan BI 7-DRRR yang diidentifikasikan sebagai (t0), Menentukan jendela peristiwa (event window)/periode pengamatan dalam pengukuran reaksi pasar. Jendela peristiwa penelitian ini selama 7 hari yang terhitung sejak tiga hari sebelum kebijakan diumumkan ( $t-3)$ hingga tiga hari setelah kebijakan diumumkan $(t+3)$, Melakukan analisis statistik deskriptif, Melakukan pengujian hipotesis, Melakukan uji sensitivitas. Uji sensitivitas bertujuan untuk menilai sejauh mana hasil penelitian akan konsisten walaupun perhitungan yang dilakukan menggunakan alat ukur yang berbeda, Pembahasan. Pembahasan dilakukan dengan menghubungkan hasil penelitian dengan teori-teori serta penelitian terdahulu yang selanjutnya diperoleh suatu simpulan akhir.

Studi peristiwa dilakukan dengan periode estimasi penelitian selama 100 hari. Waktu penelitian ini adalah tanggal 24 Oktober 2019. Untuk menilai reaksi pasar, dilakukan dengan membandingkan average abnormal return 3 hari sebelum 
dan 3 hari setelah diumumkannya penurunan BI 7-DRRR pada tahap teknik analisis data.

Data penelitian berupa data sekunder yaitu saham historis perusahaan properti dan perbankan di Bursa Efek Indonesia. Data tersebut diperoleh melalui situs resmi IDX serta yahoo.finance. Objek dalam penelitian ini adalah abnormal return saham sektor properti dan perbankan di sekitar tanggal pengumuman penurunan BI 7-DRRR. Populasi yaitu saham-saham dari sektor properti dan perbankan yang tercatat di Bursa Efek Indonesia dari bulan Juni 2019 s/d November 2019.

Hasil penelitian akan lebih akurat apabila menggunakan sampel yang tepat. Penelitian ini membutuhkan sampel yang memiliki kriteria tertentu. Sampel penelitian menggunakan saham-saham perusahaan sektor properti dan subsektor perbankan di BEI, yang didasari atas pertimbangan, Tidak adanya suatu aksi korporasi yang dilakukan selama periode penelitian, dan bukan merupakan saham tidur atau aktif diperdagangkan pada pasar modal. Jumlah sampel disajikan pada Tabel 1. dan Tabel 2.

Tabel 1. Penentuan Sampel Sektor Properti

\begin{tabular}{clc}
\hline No & \multicolumn{1}{c}{ Kriteria } & Jumlah \\
\hline 1 & Saham properti BEI & 62 \\
2 & Saham tidak aktif diperdagangkan & $(31)$ \\
3 & Corporate Action & $(1)$ \\
& $\quad$ Jumlah Sampel & 30 \\
\hline
\end{tabular}

Sumber: Data Penelitian, 2020

Uji normalitas perlu dilakukan sebelum tahap analisis data. Tujuannya adalah untuk menilai data terdistribusi normal atau tidak. Uji KolmogorovSmirnov digunakan sebagai metode uji normalitas data, yang mana pengambilan keputusan dilihat dari nilai signifikansinya. Apabila nilai signifikansi $>0,05$ maka data terdistribusi normal. Begitupun sebaliknya, apabila signifikansi $\leq 0,05$ maka data tidak terdistribusi normal.

Tabel 2. Penentuan Sampel Sektor

\begin{tabular}{clc}
\hline No & \multicolumn{1}{c}{ Kriteria } & Jumlah \\
\hline 1 & Saham perbankan BEI & 43 \\
2 & Saham tidak aktif diperdagangkan & $(11)$ \\
3 & Corporate Action & $(0)$ \\
& $\quad$ Jumlah Sampel & 32 \\
\hline
\end{tabular}

Sumber: Data Penelitian, 2020

Data yang terdistribusi normal akan dianalisis menggunakan paired samples $t$-test. Tujuan teknik ini adalah untuk mengetahui adanya perbedaan rata-rata dua sampel yang sama, yang mana masing-masing sampel memiliki dua data yang berbeda. Pengambilan keputusan hasil paired samples t-test dinilai dari tingkat signifikansinya. Tingkat signifikansi $\leq 0,05$ berarti Ha diterima, sedangkan tingkat signifikansi $>0,05$ maka Ha ditolak. Data yang tidak berdistribusi normal akan dianalisis menggunakan wilcoxon signed rank test. Tujuan dari teknik ini adalah untuk mengetahui perbedaan dua kelompok data berpasangan. Interpretasi hasil pengujian wilcoxon signed rank test dilihat pada nilai Sig. (2-tailed). Apabila tingkat signifikansi $\leq$ 0,05, maka Ha diterima, sedangkan signifikansi > 0,05 maka Ha ditolak. 
Uji sensitivitas juga digunakan sebagai pengujian tambahan. Uji sensitivitas dilakukan dengan tujuan meningkatkan keyakinan atas hasil penelitian walaupun dalam perhitungannya menggunakan parameter / alat ukur yang berbeda. Model penelitian utama menggunakan perhitungan return ekspektasi metode market-adjusted model dalam menentukan abnormal return. Uji sensitivitas dilakukan dengan membandingkan abnormal return yang terhitung menggunakan market adjusted model, mean-adjusted model, dan market model.

\section{HASIL DAN PEMBAHASAN}

Pengujian Hipotesis $1\left(\mathrm{H}_{1}\right)$ dimulai dari analisis statistik deskriptif. Hasil analisis statistik deskriptif menjelaskan data penelitian dengan cara memberikan gambaran atau mendeskripsikan dengan menampilkan nilai terendah, nilai tertinggi, rata-rata, serta standar deviasi. Tabel 3, menyajikan hasil analisis atas abnormal return perusahaan perbankan pada sebelum dan setelah peristiwa, sebagai berikut.

Tabel 3. Analisis Statistik Deskriptif Rata-rata Abnormal return (AAR) Sektor Perbankan

\begin{tabular}{lccccc}
\hline & $\mathrm{N}$ & Minimum & Maximum & Mean & Std. Deviation \\
\hline AAR Sebelum & 32 & $-0,016$ & 0,018 & $-0,001$ & 0,009 \\
AAR Setelah & 32 & $-0,014$ & 0,023 & 0,000 & 0,007 \\
Valid N (listwise) & 32 & & & & \\
\hline
\end{tabular}

Sumber: Data Penelitian, 2020

Tabel 3, memperlihatkan bahwa sebelum pengumuman diumumkan, nilai terendah AAR atas 32 perusahaan sampel bernilai -0,016 yaitu (MCOR) dan nilai AAR tertinggi bernilai sebesar 0,018 yaitu (BNLI). Nilai standar deviasi AAR sebelum peristiwa sebesar 0,00952 yang berarti bahwa perbedaan AAR sebelum peristiwa terhadap mean sebesar 0,009. Nilai terendah dari AAR setelah peristiwa diperoleh perusahaan (BKSW) sebesar 0,014, sedangkan nilai tertingginya diperoleh perusahaan (BINA) sebesar 0,023. Nilai standar deviasi AAR setelah peristiwa sebesar 0,007 yang berarti bahwa perbedaan AAR setelah peristiwa terhadap mean sebesar 0,007.

Tabel 4. AAR Sektor Perbankan

\begin{tabular}{|c|c|c|c|c|c|c|c|c|}
\hline & \multicolumn{5}{|c|}{ Paired Differences } & \multirow{3}{*}{$t$} & \multirow{3}{*}{$d f$} & \multirow{3}{*}{$\begin{array}{l}\text { Sig. } \\
(2- \\
\text { tailed })\end{array}$} \\
\hline & \multirow[b]{2}{*}{ Mean } & \multirow{2}{*}{$\begin{array}{c}\text { Std. } \\
\text { Deviation }\end{array}$} & \multirow{2}{*}{$\begin{array}{l}\text { Std. } \\
\text { Error } \\
\text { Mean }\end{array}$} & \multicolumn{2}{|c|}{$\begin{array}{l}\text { 95\% Confidence } \\
\text { Interval of the } \\
\text { Difference }\end{array}$} & & & \\
\hline & & & & Lower & Upper & & & \\
\hline $\begin{array}{l}\text { AAR } \\
\text { Sebelum } \\
\text { - AAR } \\
\text { Setelah }\end{array}$ & $-0,002$ & 0,012 & 0,002 & $-0,006$ & 0,002 & $-0,904$ & 31 & 0,373 \\
\hline
\end{tabular}

Sumber: Data Penelitian, 2020

Uji normalitas data pada sektor perbankan menggunakan variabel AAR. Nilai probabilitasnya diperoleh sebesar $0,200>0,05$ yang berarti bahwa data terdistribusi normal. Uji paired samples $t$-test dilakukan untuk pengujian hipotesis $1\left(\mathrm{H}_{1}\right)$ yaitu terdapat perbedaan average abnormal return sebelum dan setelah 
pengumuman penurunan BI 7-DRRR pada sektor perbankan. Tabel 4, memperlihatkan hasil uji paired samples $t$-test yang memperoleh nilai Sig. sebesar $0,373>0,05$, yang berarti bahwa $\mathrm{H}_{1}$ ditolak sehingga tidak terdapat perbedaan yang signifikan antara AAR sebelum dan setelah pengumuman penurunan BI 7DRR pada sektor perbankan.

Pengujian Hipotesis 2 dimulai dari analisis statistik deskriptif. Tabel 5, menyajikan hasil statistik deskriptif atas AAR perusahaan properti sebelum dan setelah peristiwa sebagai berikut.

Tabel 5. Analisis Statistik Deskriptif Rata-rata Abnormal return (AAR) Sektor Properti

\begin{tabular}{cccccc}
\hline & $\mathrm{N}$ & Minimum & Maximum & Mean & $\begin{array}{c}\text { Std. } \\
\text { Deviation }\end{array}$ \\
\hline AARsebelum & 30 & $-0,043$ & 0,060 & $-0,000$ & 0,017 \\
AARsetelah & 30 & $-0,025$ & 0,138 & 0,009 & 0,035 \\
Valid N (listwise) & 30 & & & & \\
\hline
\end{tabular}

Sumber: Data Penelitian, 2020

Tabel 5, menunjukkan bahwa sebelum pengumuman diumumkan, AAR terendah dari 30 perusahaan sampel sebesar $-0,04340$ (RDTX) dan nilai tertinggi adalah sebesar 0,06050 (MPRO). Standar deviasi AAR sebelum peristiwa diperoleh sebesar 0,017 yang berarti bahwa perbedaan AAR sebelum peristiwa terhadap mean sebesar 0,017. Setelah pengumuman diumumkan, nilai AAR terendah adalah sebesar -0,025 (DART) dan nilai AAR tertinggi adalah sebesar 0,138 (MPRO). Nilai standar deviasi AAR setelah peristiwa diperoleh sebesar 0,035 yang berarti bahwa perbedaan AAR setelah peristiwa terhadap mean sebesar 0,035.

Hasil uji normalitas atas data sektor properti menggunakan variabel AAR yang menghasilkan nilai probabilitas sebesar $0,000 \leq 0,05$ maka data tidak terdistribusi normal. Maka dari itu pengujian hipotesis menggunakan wilcoxon signed rank test. Teknik ini dilakukan untuk pengujian hipotesis $2\left(\mathrm{H}_{2}\right)$ yaitu terdapat perbedaan average abnormal return sebelum dan setelah pengumuman penurunan BI 7-DRRR pada sektor properti. Berikut hasil uji analisis data pada sektor properti.

Tabel 6. Wilcoxon signed rank test Pada Sektor Properti

\begin{tabular}{cc}
\hline Tabel 6. Wilcoxon signed rank test Pada Sektor Properti \\
\hline AAR Setelah - AAR Sebelum \\
\hline Asymp. Sig. (2-tailed) & $-0,998$ \\
0,318 \\
\hline
\end{tabular}

a. Wilcoxon Signed Ranks Test

b. Based on negative ranks

Sumber: Data Penelitian, 2020

Tabel 6, menampilkan hasil pengujian pada sektor properti yang memperoleh nilai Sig. (2-tailed) sebesar 0,318 >0,05, sehingga $\mathrm{H}_{2}$ ditolak. Maka dari itu, tidak terdapat perbedaan antara AAR sebelum dan setelah penurunan BI 7-DRRR pada tanggal 24 Oktober 2019.

Pengumuman penurunan BI 7-DRRR tidak menimbulkan abnormal return yang signifikan baik pada sektor perbankan maupun properti. Schrey \& Hafdísarson (2017) menjelaskan bahwa pengumuman perubahan suku bunga dapat menyebabkan reaksi pasar apabila pasar tidak mengantisipasi pengumuman tersebut secara keseluruhan. Apabila pengumuman penurunan BI 7-DRRR merupakan suatu informasi yang tidak diduga oleh pasar, maka 
akan menyebabkan perubahan harga keseimbangan baru. Penelitian ini membuktikan bahwa abnormal return antara sebelum dan setelah pengumuman tidak memiliki perbedaan atas diumumkannya penurunan BI 7-DRRR yang mencerminkan bahwa pasar sudah mengantisipasi pengumuman tersebut. Yu \& Zhang (2016) menjelaskan bahwa tidak adanya reaksi pasar atas pengumuman ini juga dapat disebabkan oleh adanya long-term effect.

Uji sensitivitas penelitian ini dilakukan dengan membandingkan hasil pengujian reaksi pasar yang menggunakan market-adjusted model dengan perhitungan yang menggunakan model lainnya yaitu market model dan meanadjusted model. Tabel 7, menyajikan perbandingan hasil pengukuran dari kedua model tersebut, sebagai berikut.

Tabel 7. Perbandingan Hasil Uji Beda Reaksi Pasar atas Pengumuman Penurunan BI 7-Day Reverse Repo Rate

\begin{tabular}{lcc}
\hline Asymp Sig. (2-tailed) & Sektor Perbankan & Sektor Properti \\
\hline Market-Adjusted Model & 0,373 & 0,318 \\
Market Model & 0,474 & 0,910 \\
Mean-Adjusted Model & 0,039 & 0,393 \\
\hline
\end{tabular}

Sumber: Data Penelitian, 2020

Berdasarkan Tabel 7, hasil pengujian terhadap abnormal return dengan metode market model baik pada sektor perbankan maupun properti menunjukan tingkat signifikansi diatas 5\% yakni masing-masing sebesar 0,474 dan 0,910 yang berarti bahwa perhitungan dari metode ini memperoleh hasil yang sama yaitu AAR sebelum peristiwa tidak berbeda dengan AAR setelah peristiwa diumumkan. Hasil penelitian konsisten walaupun menggunakan metode perhitungan return ekspektasi yang berbeda.

Hasil pengujian terhadap abnormal return dengan metode mean-adjusted model pada sektor properti juga menunjukan nilai probabilitas yang lebih besar dari tingkat signifikansi 5\% $(0,05)$ yaitu sebesar 0,393 . Namun, pengujian pada sektor perbankan dengan metode mean-adjusted model memberikan hasil yang berbeda yaitu menunjukkan nilai probabilitas yang lebih kecil dari tingkat signifikansi $5 \%(0,05)$, yang berarti bahwa hasil pengujian akan berbeda apabila dilakukan dengan metode mean-adjusted model.

\section{SIMPULAN}

Hasil penelitian pada sektor properti maupun perbankan menunjukkan bahwa AAR antara sebelum dan setelah pengumuman tidak memiliki perbedaan yang cukup signifikan, maka disimpulkan bahwa pasar tidak bereaksi atas pengumuman penurunan BI 7-DRRR pada tanggal 24 Oktober 2019. Hal ini mencerminkan bahwa kebijakan tersebut tidak mengandung informasi yang relevan baik untuk sektor perbankan maupun untuk sektor properti di BEI. Hal ini dapat disebabkan oleh investor yang menganggap penurunan suku bunga ini tidak dapat mempengaruhi kinerja perusahaan dalam jangka pendek serta mempertimbangkan sentimen-sentimen lainnya yang ada pada pasar. Maka dari itu, investor masih melakukan tindakan wait and see yang dapat dikatakan bahwa tidak adanya perubahan keputusan investor atas pengumuman ini. 
Adapun keterbatasan dalam penelitian ini yaitu menggunakan satu alat ukur saja dalam menentukan reaksi pasar yaitu abnormal return. Saran bagi penelitian selanjutnya yaitu menguji reaksi pasar dengan membedakan sampel atau karakteristik perusahaan seperti ukuran perusahaan, internasionalisasi, dan sebagainya. Selain itu, penambahan variabel lain sebagai pengukuran reaksi pasar juga disarankan untuk memperoleh hasil penelitian yang lebih akurat.

\section{REFERENSI}

Amarasinghe, A. (2015). Dynamic Relationship between Interest Rate and Stock Price $\square$ : Empirical Evidence from Colombo Stock Exchange. International Journal of Business and Social Science, 6(4), 92-97.

Anjani, N. P. P., \& Wahyuni, M. A. (2019). Analisis Reaksi Investor Terhadap Pengaruh Peristiwa Kenaikan Suku Bunga Bi Akibat Kenaikan Suku Bunga the Fed Pada Indeks Saham Lq45. 1(June 2018), 85-95.

Dadrasmoghadam, A., \& Akbari, M. R. S. (2015). Relationship between Financial Ratios in the Stock Prices of Agriculture-Related Companies Accepted On the Stock Exchange for Iran. Research Journal of Fisheries and Hydrobiology, 10(9), 586-591.

Dewi, S. R. (2017). Reaksi Pasar Atas Pengumuman Paket Kebijakan Ekonomi X Tentang Daftar Negatif Investasi. Jurnal Ilmiah Akuntansi Dan Bisnis, 12(2), 104-114.

Fama, E. F. (1970). Efficient Capital Market: A Review of Theory and Empirical Work. The Journal of Finance, 25(2), 383-417.

Fitriyana, S. (2017). Pengaruh Faktor Internal Dan Bi Rate Terhadap Profitabilitas Bank Umum Syariah Periode 2012-2015. Jurnal Ilmu Manajemen (JIM), 5(3).

Gumanti, T. A. G., Savitri, E., Nisa, N. W., \& Sri Utami, E. (2018). Event Study on the Crash of Airasia Plane: A Study on Travel and Leisure Companies Listed at Malaysian Stock Market. Jurnal Akuntansi Dan Keuangan, 20(1), 20. https://doi.org/10.9744/jak.20.1.20-26

Hajilee, M., \& Nassel, O. M. Al. (2017). The Impact Of Interest Rate Volatility On Stock Market Development: Evidence From Emerging Markets. The Journal of Developing Areas, 51(2), 301-313. https:// doi.org/ doi:10.1353/jda.2017.0046.

Hartono, J. (2017). Teori Portofolio dan Analisis Investasi. BFPE.

Indriyani, S. (2016). Analisis Pengaruh Inflasi Dan Suku Bunga Terhadap Pertumbuhan Ekonomi Di Indonesia Tahun 2005 - 2015. Jurnal Manajemen Bisnis Krisnadwipayana, 4(2). https:// doi.org/10.35137/jmbk.v4i2.37

Karim, A. (2015). Analisis Pengaruh Faktor Internal Dan Eksternal Terhadap Return Saham Perusahaan Manufaktur Yang Terdaftar Di Bursa Efek Indonesia (BEI) Periode 2010-2012. Media Ekonomi Dan Manajemen, 30(1), 4155.

Kurniasari, W., Wiratno, A., \& Yusuf, M. (2018). Pengaruh Inflasi dan Suku Bunga Terhadap Return Saham Dengan Profitabilitas Sebagai Variabel Intervening di Perbankan yang Terdaftar di Bursa Efek Indonesia Tahun 2013-2015. Journal of Accounting Science, 2(1), 67. https://doi.org/10.21070/jas.v2i1.1216

Mahendra, I. K. R. (2019). Reaksi Pasar Terhadap Kenaikan Bank Indonesia 7 Day Reverse Repo Rate Tanggal 15 Agustus 2018. E-Jurnal Akuntansi Universitas Udayana, 27, 2066-2099. https://doi.org/DOI: 
https:// doi.org/10.24843/EJA.2019.v27.i03.p16

Maslikha, H., Puspitaningtyas, Z., \& Prakoso Program Studi Administrasi Bisnis, A. (2017). Pengaruh Inflasi dan BI Rate terhadap IHSG. Vol. IV Edisi, 1, 62-67.

Okechukwu, I. A., Samuel Mbadike, N., Geoffrey, U., \& Ozurumba, B. A. (2019). Effects of Exchange Rate, Interest Rate, and Inflation on Stock Market Returns Volatility in Nigeria. International Journal of Management Science and Business Administration, 5(6), 38-47. https://doi.org/10.18775/ijmsba.1849-56645419.2014.56.1005

Okoro, E., Ogoma, N., \& Ume, K. (2018). Interest Rate and Investment in Money Market Instruments in a Developing Economy: A Case of Nigeria. Journal of Economics, Management and Trade, 20(2), 1-9. https://doi.org/10.9734/jemt/2017/38302

Oshaibat, S., \& Majali, A. (2016). The Relationship Between Stock Returns and Each of Inflation, Interest Rates, Share Liquidity and Remittances Of Workers in the Amman Stock Exchange. Journal of Internet Banking and Commerce, 21(2).

Pratama, I., \& Tjun Tjun, L. (2018). Pengaruh Suku Bunga Acuan dan Nilai Kurs Tengah Valuta Asing Terhadap Return Saham. Jurnal Akuntansi Maranatha, 9(2), 180-185. https://doi.org/10.28932/jam.v9i2.486

Pratiwi, K. R. D. I. (2018). Reaksi Pasar Modal Indonesia Atas Pengumuman Kenaikan Tingkat Suku Bunga Acuan Oleh Fed di AS. 25, 1966-1993.

Ramsharan, N. (2019). Impacts of Interest Rate on Stock Market: Challenges for Investors. International Journal of Innovative Science, Engineering $\mathcal{E}$ Technology, $6(4), 228-236$.

Rjoub, H., Civcir, I., \& Resatoglu, N. G. (2017). Micro and Macroeconomic Determinants of Stock Prices: The Case Of Turkish Banking Sector. Romanian Journal of Economic Forecasting, 10(1), 150-167.

Sari, R. (2019). Pengaruh Suku Bunga Terhadap Indeks Harga Saham Gabungan (IHSG) Dimediasi Nilai Tukar pada Sektor Properti di Bursa Efek Indonesia (BEI). Economix, 7(1), 25-36.

Schrey, A. R., \& Hafdísarson, A. R. (2017). Effect of Interest Rate Changes on Stocks : Is the Icelandic Market Efficient? 1-57.

Wibisono, B. S., \& Octaviani, D. (2019). Analisis Pengaruh Variabel Makroekonomi Terhadap Indeks Harga Saham Properti Dan Keuangan Di Indonesia. Media Ekonomi, 25(2), 133. https://doi.org/10.25105/me.v25i2.5000

Wibowo, A. (2017). Reaksi Investor Pasar Modal Indonesia Terhadap Paket Kebijakan Ekonomi Tahap I Jokowi - JK ( Studi pada Saham LQ 45 Periode Agustus 2015 - Pebruari 2016 ). Media Ekonomi Dan Manajemen, 32(1). https://doi.org/10.24856/mem.v32i1.452

Wuhan, Suyuan, L., \& Khurshid, A. (2015). The Effect of Interest Rate on Investment: Empirical Evidence of Jiangsu Province, China. Journal of International Studies, 8(1), 81-90. https://doi.org/10.14254/20718330.2015/8-1/7

Yu, L., \& Zhang, A. (2016). The Market Reaction to Interest Rate Change: The Effect of Financial Leverage. 